\title{
Essay
}

\section{The Ideology of Division: Behavior Modification Welfare Reform Proposals}

\author{
Lucy A. Williams ${ }^{\dagger}$
}

During their Administration and throughout the 1992 Presidential campaign, President Bush and Vice President Quayle claimed that the welfare initiatives of the 1960's are responsible for the persistence of poverty in the United States and the urban problems demonstrated so graphically by the Los Angeles riots this spring. ${ }^{1}$ Their statements are part of a disturbing effort to divert attention from the structural problems of our society and to focus instead on the so-called deviance of the poor. The rhetoric of the current "welfare reform"2 debate goes something like this: Aid to Families with Dependent Children (AFDC) recipients are themselves responsible for their poverty because they have not "pulled themselves up by their bootstraps"; they are dysfunctional mothers incapable of fitting into mainstream society, and they are economically and emotionally

$\dagger$ Associate Professor, Northeastern University Law School; A.B. 1969, Baylor University; J.D. 1974, University of Chicago.

The author expresses her appreciation to Jean Hardisty and Deborah Harris for insightful discussions, to her colleague Judith Olans Brown for meticulous editing, to Clare Dalton, Patricia DeLessio, Mark Greenberg, Jim Rowan, and Steve Savner for their thoughtful comments on earlier drafts, and to Hillary Botein, Kim LaDue, and Marchell Wesaw for their capable research assistance.

1. Michael Wines, White House Links Riots to Welfare, N.Y. TMME, May 5, 1992, at A1; Seth Sutel, Quayle: Welfare to Blame, BostoN GLOBE, May 14, 1992, at 13. The rioting in South Central Los Angeles was in response to the acquittal of the white police officers who had been videotaped beating an AfricanAmerican suspect, Rodney King.

2. I put the term "welfare reform" in quotation marks because, in my opinion, the most recent state initiatives are designed not to solve the multiple problems faced by poor women and children or to improve the economic conditions for such families, but rather to penalize them for their actions and to reduce welfare rolls. 
atrophied because of their "dependence"3 on welfare. Proponents of "welfare reform" further argue that by withholding AFDC benefits, the government can transform present recipients into productive members of society, thereby solving the intractable problems of poverty. Consistent with this rhetoric, the current "welfare reform" proposals condition AFDC eligibility on conformity with putative moral norms of society. Underlying the proposals is the belief that the receipt of assistance is debilitating. ${ }^{4}$

These concepts, always an undercurrent in American history, surfaced with new vigor in the work of conservative scholars in the early 1980's. 'The conservatives' ideas engendered several state demonstration projects, including Learnfare (loss of benefits if a child misses a certain number of days of school or fails to average a certain grade), ${ }^{6}$ Family Cap (loss of benefits for additional children), ${ }^{7}$ Bridefare or Wedfare (small monetary incentives given to a mother to marry the father of her child combined with the loss of benefits for additional children), ${ }^{8}$ incentives for recipients to use Norplant contraception, ${ }^{9}$ and benefit reductions if the mother pays her rent irregularly or fails to obtain medical treatment for her children. ${ }^{10}$ The idea behind all of these projects is the same:

3. The "dependency" concept has always played a role in the cash assistance debate, but has undergone substantial transformation. Compare Charles A. Reich, The New Property, 73 YALE L.J. 733, 785 (1964) (arguing that welfare benefits are designed to "preserve the self-sufficiency of the individual") with LAWRENCE N. MEAD, BEYOND ENTITLEMENT: THE SOCIAL OBLIGATIONS OF CITIZENSHIP 41 (1986) (accusing welfare state of undermining discipline and creating great reliance on government).

4. The current welfare debate catapulted to front-page news when President Bush endorsed Wisconsin's Family Cap demonstration project, which denies additional AFDC benefits to children born into an AFDC family, and adopted it as part of his "welfare reform" initiative. See Michael Kranish, Bush Backs Experimental Welfare Plan, BOSTON GLOBE, Apr. 11, 1992, at 1; Andrew Rosenthal, Bush Backs Wisconsin Attempt at Welfare Reform, N.Y. TMES, Apr. 9, 1992, at D20. (1984).

5. See, e.g., GEORGE GILDER, WEALTH AND POVERTY (1981); ChARLES MURRAY, LOSING GROUND

6. Learnfare operates in Wisconsin, Ohio, Maryland, and in modified form in Virginia. It was proposed during the 1992 state legislative sessions in Arizona, California, Colorado, Florida, Georgia, Indiana, Iowa, Louisiana, Massachusetts, Michigan, Mississippi, Missouri, New York, Oklahoma, Pennsylvania, Tennessee, and Washington. JODIE LEVIN-EPSTEIN \& MARK GREENBERG, CENTER FOR LAW AND SOCIAL POLICY, 1992 STATE AFDC LEGISLATIVE AND WAIVER ACTIONS (1992).

7. Family Cap operates in New Jersey and has been proposed during 1992 legislative sessions in Arizona, California, Colorado, Connecticut, Florida, Georgia, Iowa, Maine, Maryland, Massachusetts, Michigan, Mississippi, Missouri, Montana, Ohio, Pennsylvania, South Carolina, Virginia, and Washington. Id. Wisconsin has received a federal waiver to establish a Family Cap program, although the state legislature has not yet authorized one. See infra notes 109-110 and accompanying text.

8. Bridefare was proposed in Mississippi and Wisconsin. Jodie Levin-Epstein, A Report on State Welfare Developments, ClASP STATES NETWORK UPDATE, (Center for Law and Social Policy, Washington, D.C.), Mar. 20, 1992, at 8, 13 [hereinafter CLASP UPDATE].

9. Incentives for welfare mothers to use Norplant have been proposed in Kansas, Louisiana, Mississippi, South Carolina, and Tennessee. Id.; Tamar Lewin, A Plan to Pay Welfare Mothers for Birth Control, N.Y. TIMES, Feb. 9, 1991, at A9.

10. In January 1993, Maryland will implement a $\$ 25$ per month AFDC reduction for each preschool-age child not getting preventive health care. Jodie Levin-Epstein, HHS Approved Waivers, FAMILY MATTERS, (Center for Law and Social Policy, Washington, D.C.), July 1992, at 13-14. Maryland has also proposed a $30 \%$ reduction for mothers who do not regularly pay their rent. Rogers Worthington, The State as Stern Parent, Boston Globe, Jan. 17, 1992, at 3. 
only those women and children who conform to majoritarian middle-class values deserve government subsistence benefits.

Because projects that condition eligibility on behavior contravene the mandated eligibility requirements set forth in the Social Security Act, ${ }^{11}$ they require the United States Department of Health and Human Services (HHS) to waive the entitlement provisions under 42 U.S.C. $\S 1315$. Through this administrative mechanism, President Bush embraced the use of welfare laws to attempt to modify behavior.

This Essay analyzes two of the most popular behavior-modification models of "welfare reform" and places them in historical context. Part I reviews the historical discrimination against women and people of color in our cash assistance programs and discusses the persistent national ambivalence about welfare. Parts II and III critique the effectiveness of the Learnfare and Family Cap proposals respectively, by reviewing their stated goals and demonstrating the empirical inaccuracies of their underlying assumptions. Part IV argues that these "reform" efforts are driven by a New Right agenda, an "ideology of division" that has manipulated public opinion by highlighting racial and gender biases.

\section{BeING TRUe to OUR ROOTS: THE Historical CONTEXT FOR BEHAVIOR MODIFICATION PROPOSALS}

The United States has always been ambivalent about assisting the poor, unsure whether the poor are good people facing difficult times and circumstances or bad people who cannot fit into society. ${ }^{12}$ In this Part, I discuss how certain groups, defined primarily by race and gender, have been excluded, included, and once again excluded from public welfare programs.

Public welfare programs in the United States originated as discretionary programs for the "worthy" poor. Local asylums or poorhouses separated the deserving poor, such as the blind, deaf, insane, and eventually the orphaned, from the undeserving, comprising all other paupers including children in families, with wide variation and broad local administrative discretion. ${ }^{13}$ Even for the deserving poor, state initiatives before 1929 were usually permissive and were frequently underfunded. ${ }^{14}$

11. 42 U.S.C. $\$ 602(a)(10)(A)$ (1989) (" $[A]$ id to families with dependent children shall . . be furnished with reasonable promptness to all eligible individuals."). This provision prohibits the states from varying the categorical eligibility requirements established by the Social Security Act. King v. Smith, 392 U.S. 309, 333 (1968).

12. MiChael B. KatZ, THE UNDESERVING POOR 9-10 (1989).

13. EDWARD BERKOWITZ \& KM MCQUAD, CREATING THE WELFARE STATE: THE POLITICAL ECONOMY OF TWENTIETH-CENTURY REFORM 26 (1980); Joel F. Handler, The Transformation Of Aid To Families With Dependent Children: The Family Support Act in Historical Context, 16 N.Y.U. REV. L. \& Soc. CHANGE 457, 470-72 (1987-88).

14. FRANCES FOX PIVEN \& RICHARD A. ClOWARD, REgULATING THE POOR: THE FUNCTIONS OF PUBLIC WELFARE 48 (1971). Particularly noteworthy is that $82 \%$ of participants in these programs were widows, 
The Great Depression provided the impetus for a national framework to provide assistance to the poor. ${ }^{15}$ Local governmental entities were staggering under the costs of relief. ${ }^{16}$ In addition, the massive unemployment of previously employed, white male voters made it politically impossible to dismiss the poor as responsible for their own situation. ${ }^{17}$

With the passage of the Federal Emergency Relief Act of 1933, the federal government assumed responsibility and appropriated funds to provide cash relief through a program for all needy unemployed persons and their dependents, not just the worthy widows and orphans. ${ }^{18}$ But legislators considered cash relief a temporary measure to last only until the Depression ended. ${ }^{19}$ Consistent with the view that welfare undermines the value systems of its recipients, ${ }^{20}$ legislators believed that cash relief was emotionally debilitating, while work, in contrast, fostered dignity. ${ }^{21}$ Thus the Social Security Act of 1935 was a limited statute, targeted to specific populations in the form of three programs: unemployment insurance, old-age insurance, and federal aid to states that chose to provide cash relief to certain unemployables (the old, the blind, and the orphaned). ${ }^{22}$ Earlier, broader proposals covering all children in need-not just those without a parent-were rejected. ${ }^{23}$

From its inception, the language and administration of the Social Security Act ("the Act") allowed the exclusion of African Americans from the programs. For example, Southern Congressmen defeated statutory language that would have protected African Americans from discrimination in eligibility for old-age pensions. ${ }^{24}$ Impelled by their fear that elderly African Americans would help

and $96 \%$ were white. Of the $3 \%$ who were African American, half lived in just two states. The programs included continuous supervision of families to ensure their worthiness. WINIFRED BELL, AD TO DEPENDENT CHILDREN 9-13 (1965).

15. MIMI ABRAMOVITZ, REGULATING THE LIVES OF WOMEN: SOCIAL WELFARE POLICY FROM COLONLAL TIMES TO THE PRESENT 226-27 (1989). The significance of the cash assistance programs enacted during the New Deal is debatable. Primary enforcement of the programs was still a local responsibility; however, federal financial participation was established for the first time. Handler, supra note 13 , at 479 .

16. PIVEN \& ClowARD, supra note 14, at 66-67.

17. Michael B. KATz, IN THE Shadow OF THE POORHOUSE 211-12 (1986). Piven and Cloward juxtapose this assistance of unemployed white men to the lack of response from local relief agencies to the millions of African Americans who were displaced from the rural South by agricultural modernization in the 1950's, but who were without the political power to compel a response. PIVEN \& CLOWARD, supra note 14 , at 57 .

18. Federal Emergency Relief Act of 1933, Pub. L. No. 73-15, ch. 30, § 4(a), 48 Stat. 57.

19. BERKOWTTZ \& MCQUAD, supra note 13 , at 138.

20. See William H. Simon, The Invention and Reinvention of Welfare Rights, 44 MD. L. REV. 1, 11 n.34 (1985) (collecting sources).

21. Even in 1935, the year the Social Security Act was passed, President Roosevelt stated that "[c]ontinued dependence upon relief induces a spiritual and moral disintegration fundamentally destructive to the national fibre ...."3 ARTHUR M. SCHLESINGER, JR., THE AGE OF ROOSEVELT: THE POLITICS OF UPHEAVAL 267 (1960).

22. The result of this selection of programs was a classic continuation of the dichotomy between deserving and undeserving poor: those whose benefits were tied to attachment to the labor force were the deserving, and those who had not worked were the undeserving. KATZ, supra note 17, at 238-39.

23. BELL, supra note 14 , at 27.

24. The words mandating that relief could not be denied to any citizen if qualifications regarding age and need were met, thereby providing some protection to African Americans, were changed to provide only 
support younger African Americans, who would thus become less pliant field laborers, these same Congressmen eliminated specific language requiring that old-age benefits be "a reasonable subsistence compatible with decency and health, ${ }^{, 25}$ thereby retaining state discretion over the amount of benefits. ${ }^{26}$ African-American leaders had argued that local standards would allow "less assistance to aged Negroes than to aged whites."27

The small program that covered children living with their mothers, ${ }^{28}$ Aid to Dependent Children (ADC), assisted the children of women who were white, widowed, and had been connected to men for a substantial portion of their lives. ${ }^{29}$ Given that population, policymakers considered ADC a temporary program, effective until dependents could be covered under the portion of the Act dealing with male workers' old-age insurance. ${ }^{30}$ Although society had ambivalent feelings about supporting this population, ${ }^{31}$ it was willing to do so because the job of these white women was to provide good homes for their children. ${ }^{32}$

The legislative history of the Social Security Act allowed the states, which administered the $A D C$ program, to condition eligibility upon the sexual morality of ADC mothers through suitable-home or "man-in-the-house" rules. ${ }^{33}$ In some

that length of citizenship could not be used to exclude applicants. This allowed the exclusion of African Americans on grounds other than citizenship. PAUL H. DOUGLAS, SOCLAL SECURITY IN THE UNITED STATES: AN ANALYSIS AND APPRAISAL OF THE FEDERAL SOCIAL SECURITY ACT 87, 101 (1939).

25. STAFF OF SENATE COMM. ON FINANCE, 74TH CONG., IST SESS., SOCIAL SECURITY BILL: SUMMARY OF PROVISIONS, COMPARISON OF TEXT OF ORIGINAL BILL, AND WAYS AND MEANS REDRAFT, COMPILATION OF PROPOSED AMENDMENTS, ETC. 3 (Comm. Print 1935) (reviewing statutory language deleted by House Ways and Means Committee).

26. Jill S. Quadagno, Welfare Capitalism and the Social Security Act of 1935, 49 AM. Soc. REv. 632, 643 (1984).

27. Economic Security Act: Hearings on S. 1130 Before the Senate Comm. on Finance, 74th Cong., Ist Sess. 489 (1935) (statement of George E. Haynes, Executive Secretary, Department of Race Relations, Federal Council of Churches).

28. Mothers themselves were not covered by the program until 1950. Social Security Act Amendments of 1950, Pub. L. No. 81-734, § 323, 64 Stat. 477, 551 (codified as amended at 42 U.S.C. $\S 606$ (1989)).

29. ABRAMOVITZ, supra note 15, at 318-19; DANIEL P. MOYNIHAN, THE POLITICS OF A GUARANTEED ANNUAL INCOME 43-44 (1973).

30. BERKOWTZ \& MCQUAID, supra note 13, at 138.

31. Handler, supra note 13 , at 487 .

32. SheIlA M. ROTHMAN, WOMAN'S PROPER PLACE 221-24 (1978). Legislators viewed ADC as "designed to release from the wage-earning role the person whose natural function is to give her children the physical and affectionate guardianship necessary, not alone to keep them from falling into social misfortune, but more affirmatively to rear them into citizens capable of contributing to society." Economic Security Act: Hearings Before the House Comm. on Ways and Means on H.R. 4120, 74th Cong., 1st Sess. 48 (1935).

33. H.R. REP. No. 615, 74th Cong., 1st Sess. 24 (1935); S. REP. No. 628, 74th Cong., 1st Sess. 36 (1935) ("[The State] may, furthermore, impose such other eligibility requirements-as to means, moral character, etc.--as it sees fit.") 
states ${ }^{34}$ African-American single mothers were intentionally excluded from the welfare rolls. ${ }^{35}$ One Southern field supervisor reported:

The number of Negro cases is few due to the unanimous feeling on the part of the staff and board that there are more work opportunities for Negro women and to their intense desire not to interfere with local labor conditions. The attitude that "they have always gotten along," and that "all they'll do is have more children" is definite. . . There is hesitancy on the part of lay boards to advance too rapidly over the thinking of their own communities, which see no reason why the employable Negro mother should not continue her usually sketchy seasonal labor or indefinite domestic service rather than receive a public assistance grant. ${ }^{36}$

Contrary to the belief of the Social Security Act's drafters, the ADC program did not decline and disappear. Rather, the civil rights and welfare rights movements of the 1960's and 1970's resulted in the inclusion of many who had been excluded from the original ADC program. ${ }^{37}$ The pivotal scholarship of Professor Charles Reich in the 1960's set the stage for the concept of welfare as an entitlement to meet the enduring problem of poverty. ${ }^{38}$ Aggressive lawyering on behalf of poor people removed many of the systemic administrative barriers used to keep African-American women off the welfare rolls. ${ }^{39}$ As a

34. Alabama denied AFDC payments to the children of any mother cohabitating in or outside her home with a single or married able-bodied man; in Louisiana, any home in which an illegitimate child was born subsequent to the receipt of public assistance was considered unsuitable, and the children in that home were denied benefits. King v. Smith, 392 U.S. 309, 311, 322 (1962). The use of these behavioral rules to keep African Americans and children of unwed mothers off the welfare rolls is well documented. See ABRAMOVITZ, supra note 15, at 318-19,323-27; KATZ, supra note 12, at 253; PIVEN \& CLOWARD, supra note 14, at 138-45; Charles A. Reich, Individual Rights and Social Welfare: The Emerging Legal Issues, 74 YALE L.J. 1245, 1246-51 (1965); Charles A. Reich, Midnight Welfare Searches and the Social Security Act, 72 YALE L.J. 1347 (1963).

35. BELL, supra note 14 , at 34-35.

36. Id. (quoting Mary S. Larabee, Unmarried Parenthood Under the Social Security Act, in PROCEEDINGS OF THE NAT'L CONFERENCE OF SOCIAL WORK (1939)).

37. KATZ, supra note 12, at 267. Throughout the 1960 's, scholars debated about the existence of a "culture of poverty," which allegedly produced intergenerational poverty perpetuated by a set of values that were different than those held by the rest of society. Id., at 16-43. Proponents of the idea ranged from blaming the victims for their cultural deviance to arguing that the culture of poverty resulted from "a long history of massive deprivations and barriers." Mary Corcoran et al., Myth and Reality: The Causes and Persistence of Poverty, 4 J. POL'Y ANALYSIS \& MGMT. 516, 521 (1985).

38. Reich, supra note 3 . By the late 1960 's, most social scientists endorsed the new policy goal of a negative income tax or a minimum standard of living for everyone. Most proposals to achieve this goal would have based eligibility solely on income level, thereby removing the stigmatizing rules previously in place. President Nixon proposed a form of this concept in the 1969 Family Assistance Plan. Opposed both by conservatives (who wanted work to be more integral to benefits) and liberals (who thought the benefit level was too low and the plan too punitive), it was not enacted. DAVD ELLWOOD, POOR SUPPORT: POVERTY IN THE AMERICAN FAMILY 37 (1988). For a detailed account of this period, see generally MOYNIHAN, supra note 29.

39. JOEL F. HANDLER \& YEHESKEL HASENFELD, THE MORAL CONSTRUCTION OF POVERTY: WWELFARE REFORM IN AMERICA 117-18 (1991). The states' power to legislate morality through the categorical and financial eligibility requirements of the AFDC program was curtailed in Lewis v. Martin, 397 U.S. 552 (1970) (invalidating regulation allocating to mother for purposes of AFDC income of man who shares her home 
result the number of African Americans on the $\mathrm{AFDC}^{40}$ rolls increased dramatically, by approximately $15 \%$ between 1965 to $1971 .^{41}$ By 1971 , only $4.3 \%$ of AFDC recipients were widows. ${ }^{42}$

The early 1980's, however, saw a return to the exclusion of the "undeserving poor," now defined as those whose behavior did not adhere to middle-class values. The influential books of New Right scholars George Gilder and Charles Murray echoed the time-worn thesis that the receipt of public assistance creates immorality and dependence, undermines values, and increases poverty. ${ }^{43}$ In addition, Murray popularized the idea that poor people are motivated primarily by economic incentives. ${ }^{44}$ These ideas form the basis for the current "welfare reform" proposals. Based on individually tailored state demonstration projects supported by Bush Administration Social Security Act waivers, these proposals return to state and local governments the discretion to define who among the poor are sufficiently worthy to receive benefits. ${ }^{45}$ In the succeeding two Parts, I discuss two of the most significant proposals, Learnfare and the Family Cap.

with no legal obligation of support) and King v. Smith, 392 U.S. 309 (1968) (holding unconstitutional Alabama's disqualification from AFDC any mother cohabiting with man who was not obligated to provide support). However, specified behavior designed to effectuate a public good, such as family planning, was a sufficiently rational reason to defeat an equal protection challenge to state discretion in determining the amount of benefits. See Dandridge v. Williams, 397 U.S. 471 (1970) (upholding cap on AFDC benefits for large families, regardless of financial need).

40. The name of the program was changed to Aid to Families with Dependent Children (AFDC) in 1962. Public Welfare Amendments of 1962, Pub. L. No. 87-543, § 104(a)(3), 76 Stat. 172.

41. IRIWn Garfinkel \& SARA S. MCLANAHAN, Single MOTHERS AND THEIR CHILdREN: A NEW AMIERICAN DILEMMA 55-57 (1986).

42. MILDRED REN, DIEMMAS OF Welfare POLICY: WHY WORK STRATEGIES HAVEN'T WORKED 6 (1982). By 1973, only 5.0\% of children receiving AFDC were eligible based on the death of their parents. STAFF OF HOUSE COMM. ON WAYS AND MEANS, 102D CONG., 2D SESS., OVERVIEW OF ENTTTLEMENT PROGRAMS: BACKGROUND MATERLAL AND DATA ON PROGRAMS WITHIN THE JURISDICTION OF THE COMM. ON WAYS AND MEANS 669 (1992) [hereinafter 1992 GREEN BOOK].

43. GLDER, supra note 5, at 111-12, 114-27; MURRAY, supra note 5, at 147-66, 178-91.

There was widespread political consensus supporting the goal of the Family Support Act of 1988, Pub. L. No. 100-485, 102 Stat. 2343 (codified in scattered sections of 42 U.S.C.); that is, that women who receive AFDC become economically independent. See KATZ, supra note 12, at 229-30; Handler, supra note 13, at 501-12. Senator Moynihan, the Act's primary sponsor, articulated its underlying behavioral modification rationale:

One sentence [of President Bush's remarks is] especially notable. "We want to see the day when every American child is part of a strong and stable family." The importance of this statement is elemental. Unlike the problems of children in much of the world; age-old problems of disease, new problems of ecological disaster, the problems of children in the United States are overwhelmingly associated with the strength and stability of their families. Our problems do not reside in nature, nor yet are they fundamentally economic. Our problems derive from behavior.

136 CONG. REC. S14,416-17 (daily ed. Oct. 3, 1990) (statement of Sen. Moynihan).

44. MURRAY, supra note 5 , at $156-62$.

45. OFFICE OF MGMT. \& BUDGET, BUDGET OF THE U.S. GOV'T: FISCAL YEAR 1993 418-20 (1992). 


\section{LEARNFARE}

In July 1987, at the request of newly elected Governor Tommy G. Thompson, the Wisconsin Legislature passed the first Learnfare statute. ${ }^{46}$ Learnfare programs condition AFDC eligibility on dependent children's regular school attendance. As originally enacted, the statute targeted only teens who were themselves parents (as opposed to all teens who were part of an AFDC family unit) and provided that teens could not be sanctioned until after they had been given an opportunity to participate in a school program for "children at risk" or "school-age parents.",47 Governor Thompson used his line-item veto power ${ }^{48}$ to reshape the program: by deleting critical words and provisions, he effectively expanded Learnfare to cover all teens receiving AFDC and eliminated the requirement that teens be referred to special school programs before sanctions would be imposed against them. ${ }^{49}$ The Department of Health and Human Services (HHS) approved the federal waivers ${ }^{50}$ requested for the Learnfare portion of the Wisconsin Welfare Reform Demonstration on October 20, 1987. ${ }^{51}$

In March 1988, Wisconsin began to enforce the program against teens under fifteen and against all teen parents. At the beginning of the 1988-89 school year

46. 1987 WIS. LAWS 27 . The only other Learnfare program significantly underway is the Ohio LEAP program, which applies only to pregnant and parenting teens who receive AFDC. Under the Ohio program a teen parent with more than two unexcused absences in a month may be sanctioned. However, if the teen parent enrolls in school and meets attendance requirements, she then receives a bonus of $\$ 62$ each month (the same amount as the sanction). OHIO REV. CODE ANN. \$ 5101.20 (Anderson 1992). Virginia began a Learnfare demonstration project September 8, 1992, and Maryland is scheduled to begin one on January 1,1993 . A number of other states have implemented teen-parent initiatives under the JOBS program of the Family Support Act, Title I, Pub. L. No. 100-485, 102 Stat. 2343 (1988); see also SARA HILL ET AL., CENTER FOR LAW AND SOCLAL POLICY, BABIES ON BUSES: LESSONS FROM INITIAL IMPLEMENTATION OF THE JOBS TEEN PARENT PROVISIONS 6-10 (May 1991).

47. Enrolled 1987 Senate Bill 100 (Wis.) § $1014 \mathrm{r} \&$ u.

48. WIS. CONST. art. V, § 10(1)(b).

49. 1987 WIS. LAWS 27. State regulations provide that at the time of the sanction, the notice of the AFDC reduction must contain the name and telephone number of the school's at-risk program coordinator. WIS. ADMIN. CODE $\S$ [HSS] 201.195(8)(a)(3) (Mar. 1990).

50. 45 C.F.R. $\$ 233.90($ b)(2) (1991) specifically prohibits the denial of AFDC benefits to a minor member of an AFDC household because the child fails to attend school or to make satisfactory grades. The waiver request and the grant of waiver detail the many sections of the Social Security Act that were waived under 42 U.S.C. § 1315 (1991). See Wisconsin Department of Health and Social Services, Wisconsin Welfare Reform Package, Section 1115(a) Waiver Application to U.S. Department of Health and Human Services (May 1, 1987) (on file with author) [hereinafter 1987 Wisconsin Waiver Application].

51. See LOIS M. QUINN ET AL., EMPLOYMENT AND TRAINING INSTITUTE, DIVISION OF OUTREACH AND CONTINUING EDUCATION EXTENSION, UNIVERSITY OF WISCONSIN-MILWAUKEE, REPORT ON THE LEARNFARE EVALUATION 37 (Jan. 1991); Letter from Wayne A. Stanton, Administrator, U.S. Department of Health and Human Services, to Timothy Cullen, Secretary, Wisconsin Department of Health and Social Services, at 3 (Oct. 20, 1987) (on file with author). "[O]nly perfunctory attention was paid by state and Federal officials to the evaluation requirement that is presumably a quid pro quo for granting a state's waiver request." Wisconsin Learnfare Program: Hearing Before the Subcomm. on Social Security and Family Policy of the Senate Comm. on Finance, 101st Cong., 2d Sess. 50 (1990) [hereinafter Hearings] (statement of Thomas J. Corbett, Associate Scientist, Institute for Research on Poverty). 
the State expanded the program to include all teen dependents living with a parent. $^{52}$

Under the program, a teen on AFDC who misses ten unexcused full days of school in a semester is monitored monthly thereafter, and is "sanctioned" if she or he misses two unexcused full days of school in any month. ${ }^{53} \mathrm{~A}$ sanction reduces the family's AFDC grant by the entire amount designated for the teen. For example, for a family consisting of a mother and two children, this sanction results in a reduction of $\$ 77.60$ a month from a total grant of $\$ 517.60 .{ }^{54}$ During the $1988-89$ and $1989-90$ school years, an average of 2,125 students were sanctioned each month. AFDC families lost $\$ 3,080,000$ during 1989 alone. 55

There are two official goals of the Wisconsin program. First, the program is intended to ensure that more teenagers on AFDC complete high school or its equivalent and thereby acquire the minimum level of education needed to become productive citizens. Second, the program seeks to establish a relationship of mutual responsibility between the State and AFDC recipients: the State provides assistance to recipients in getting off, and recipients undertake education, training, and job searches that will help them become selfsufficient. ${ }^{56}$ At first glance, these goals seem benign; indeed, the notions that children should stay in school and that parents should be responsible for their children are hardly controversial. However, in historical context and in actual operation, Learnfare reinforces the myth that social problems such as truancy are caused by the deviant behavior of welfare recipients.

Why did this program, at this time, emerge to respond to this perceived crisis? The answer to this question requires an examination of the underlying premises of Learnfare. Such an examination reveals that Learnfare is based on a series of empirically faulty assumptions. Consequently, it is not surprising

52. QUINN ET AL., supra note 51, at 21. Although the statute as signed subjected all AFDC teens to Learnfare, the Wisconsin Department of Health and Social Services limited the nonparent teen population to those living with a natural or adoptive parent. WIS. ADMIN. CODE $\S$ [HSS] 201.195(3)(k) (Mar. 1990). Subsequent legislation codified this limitation. 1987 WIS. LAWs 1664.

In June 1990, HHS extended the federal waiver from September 1991 to September 1994 and approved the application of Leamfare to all AFDC children aged six and older. Letter from Jo Anne B. Bamhart, Assistant Secretary for Family Support, U.S. Department of Health and Human Services, to Patricia A. Goodrich, Secretary, Wisconsin Department of Health and Social Services (June 6, 1990) (on file with author). The waiver extension required the counties in which $92 \%$ of the sanctioned teens reside to provide case management services when it imposed a sanction and included additional funding for social services. Id.; see Hearings, supra note 51, at 8-9, 11 (testimony of Jo Anne B. Bamhart, Assistant Secretary for Family Support, U.S. Department of Health and Human Services).

53. Wis. Admin. Code $\S \S[H S S] ~ 201.195(3)(\mathrm{g}),(4)(\mathrm{b})(2)$ (Mar. 1990); JOHN PAWASARAT \& LOIS QUINN, EMPLOYMENT AND TRAINING INSTITUTE, DIVISION OF OUIREACH AND CONTINUING EDUCATION, UNIVERSITY OF WISCONSN-MILWAUKEE, THE IMPACT OF LEARNFARE ON MILWAUKEE COUNTY SOCIAL SERVICE CLIENTS 3 (1990).

54. A detailed table of sanctions by family size is contained in QUINN ET AL., supra note 51, at 25.

55. State of Wisconsin Legislative Audit Bureau 90-23, An Evaluation of Learnfare Program Administration, Department of Health and Social Services 5 (Jul. 1990) (on file with author) lhereinafter Legislative Audit Bureau Evaluation].

56. 1987 Wisconsin Waiver Application, supra note 50, at 3. 
that the Wisconsin program - and for that matter any Learnfare program-will fail to achieve its goals. ${ }^{57}$ In recent years national high school dropout rates have declined dramatically: the percentage of white adults between twenty-five and twenty-nine years old who have not completed high school dropped from $36.3 \%$ in 1960 to $13.2 \%$ in 1985; for African Americans the figure dropped from $60 \%$ in 1960 to $17.6 \%$ in $1985 .^{58}$ Ninety-two percent of the AFDC teens subject to Learnfare are meeting the school attendance requirements; ${ }^{59}$ only $8 \%$ are sanctioned. Moreover, Wisconsin's AFDC rolls had begun to decline in mid-1986. ${ }^{60}$ Nevertheless, this data neither dampened the support for a punitive program for AFDC recipients nor altered the perception of a welfare or underclass crisis.

\section{A. Learnfare as a Method to Reduce High School Dropout Rates}

If Learnfare is to achieve its first stated goal, curbing the high school dropout rate, several assumptions must be made: (1) the mother whose teenager skips school is exercising her free choice within a wide range of options in allowing the child to be truant; (2) the reason for the failure to attend school is endemic to the child's family, not to external causes; and (3) teens are motivated by economic incentives targeted at the family.

57. Federal regulations require that a governmental regulatory program be administered in a uniform and objective manner. 45 C.F.R. $\$ 233.10$ (a)(1)(iv) (1991). The Wisconsin experience suggests many problems, including poor school recordkeeping, a wide variation in attendance policies among school districts, and a fast track, noncorrective implementation. These will thwart any state's attempt at compliance. Legislative Audit Bureau Evaluation, supra note 55, at 10-18.

In a sample of administrative hearing decisions regarding appeal of sanctions, $84 \%$ struck down the Learnfare sanction as inconsistent with the regulations, and an additional $8 \%$ were upheld only because the appeal was filed after the statutory time limit. Legislative Audit Bureau Evaluation, supra note 55, at 10-11. These errors caused irreparable harm to AFDC families. For example, a computer error, which resulted in a three-month cut in the benefits received by a family headed by a pregnant teen, caused the family to become homeless. George Gerharz, Wisconsin's Learnfare: A Bust, N.Y. TMME, Jan. 29, 1990, at A23. In another case, a mother of three high school students periodically lost up to one half of the $\$ 617.00$ she received each month as a result of administrative errors. Eric Harrison, Truancy Punishment Hitting Home, L.A. TMES, July 1, 1990, at A20. The community affairs director of Milwaukee schools admitted that as many as 50 errors a month occurred because of administrative problems. Id. at A21.

The level of record-keeping errors that resulted in sanctions led to a court order on July 10, 1990, enjoining the state from sanctioning as many as 3,200 teens attending Milwaukee Public Schools. Kronquist v. Goodrich, No. 89-C-1376 (E.D. Wis. July 10, 1990). In an October 23, 1990 stipulation in the case, the state agreed to verify students' attendance records before imposing sanctions, investigate teens' reasons for absences, and issue notices to the teens and their families when they were placed in monitoring status prior to sanctions. Kronquist v. Goodrich, No. 89-C-1376 (E.D. Wis. Oct. 23, 1990).

58. Christopher Jencks, What is the Underclass-And is It Growing?, 12 Focus, Spring \& Summer 1989, at 24, cited in Thomas Corbett et al., Learnfare: The Wisconsin Experience, 12 Focus, Fall \& Winter 1989 , at 2.

59. Hearings, supra note 51, at 61 (statement of Patricia A. Goodrich, Secretary, Wisconsin Department of Health and Social Services).

60. In 1986, the year before Learnfare was enacted, the number of AFDC recipients dropped from 307,584 in April to 300,979 in June, and 296,528 in September. SOCIAL SECURITY ADMINISTRATION, UNITED STATES DEPARTMENT OF HEALTH AND HUMAN SERVICES, SOCIAL SECURTTY BULLETIN, March 1988, at 70; SOCLAL SECURTY ADMINISTRATION, UNTTED STATES DEPARTMENT OF HEALTH AND HUMAN SERVICES, SOCIAL SECURITY BULLETIN, December 1988, at 46. 
These assumptions ignore both the psychology of teenagers and the realities of poverty. Many of the choices that middle-class families make are inconceivable to poor women who do not have the option of sending their rebellious children to a different school system or to a parochial or private school. They cannot simply move to a less drug-infested neighborhood or put their children into therapy or other specialized counseling. ${ }^{61}$ They may not have the money to travel to school for parent-teacher conferences, or to pay for child care for other children while attending them. ${ }^{62}$ Even if a mother can ensure that a teen gets to school every morning, she cannot stay there all day, every day, to enforce attendance. As a Milwaukee assistant principal stated, sanctioned students "are not going to realize the value of an education by docking their parents. We've had youngsters brought here by their Learnfare parents at $8 \mathrm{o}^{\prime} \mathrm{clock}$, and at 9 0 'clock they're gone. It's in one door and out the other."63 Moreover, Learnfare ignores both the wealth of literature demonstrating why teens drop out of school and the many existing programs and strategies to get them to return or remain in school. ${ }^{64}$ The motivations for dropping out of school are complex and do not disappear with a simple solution, however politically attractive. ${ }^{65}$

Interestingly, a staff memo from the Wisconsin Department of Health and Social Services (DHSS) originally recommended that, in spite of Governor Thompson's veto of this provision, teens should be referred to social services prior to the imposition of any sanction:

Some kids have problems that prevent them from attending school or learning if they are in school, such as drug or alcohol abuse, or emotional problems due to abuse or neglect. These teens are most likely

61. Social services, such as case management, alternative education, children-at-risk programs, and drug, alcohol and child abuse services for the Learnfare population in the Milwaukee Public Schools are woefully insufficient. Legislative Audit Bureau Evaluation, supra note 55, at 28-33. For example, in one middle school, a half-time social worker is solely responsible for the school's entire 600 student enrollment, of whom $75 \%$ are in AFDC families. With the other half of her time, she is solely responsible for a 1000 student school. Twelve weeks into the semester she had not addressed any of her truancy referrals because she was addressing other problems that "are more pressing than attendance." Id. at 29. Not surprisingly, prior to entry of the Kronquist injunction, more than $75 \%$ of those sanctioned were in Milwaukee County. Corbett et al., supra note 58 , at 5 .

62. See JONATHON KOZOL, SAVAGE INEQUALITIES: CHILDREN IN AMERICA's SCHOOLs (1992) (discussing inner-city school systems and conditions faced by poor families).

63. Kenneth J. Cooper, Financial Penalties Prove No Easy Solution To Dropout Problem, WASH. POST, Feb. 16, 1990, at A3 (quoting Robert Griffin, Assistant Principal, North Division High School).

64. See, e.g., CENTER FOR THE STUDY OF SOCIAL POLICY, DROPPING OUT OF HIGH SCHOOL: A LTTERATURE REVIEW (1986); JANICE EARLE, NATIONAL ASSOCIATION OF STATE BOARDS OF EDUCATION, FEMALE DROPOUTS: A NEW PERSPECTIVE (1989); Michelle Fine, Why Urban Adolescents Drop into and out of Public High School, 87 TCHRS. C. REC. 393 (1986); Mark W. Roosa, Adolescent Mothers, School Drop-Outs and School Based Intervention Programs, 35 FAM. REL. 313 (1986); Gary G. Wehlage \& Robert A. Rutter, Dropping Out: How Much Do Schools Contribute to the Problem?, 87 TCHRS. C. REC. 374 (1986).

65. See, e.g., Cooper, supra note 63, at A3. Cooper interviewed Milwaukee teen paren Lorraine Bragg, who was sanctioned for dropping out of school. She stated that her reason for dropping out of school was that she felt classmates "were low-rating me because I had a child." Id. Rather than return to school, she received money from her boyfriend. She later returned to an altemative school established for young mothers because "she was jealous of her sister, a former dropout who was back in school and doing well." Id. 
to be sanctioned because parents will be unable to deal with them. They also may be subjected to further abuse or kicked out of the home altogether. ${ }^{66}$

The Wisconsin administration rejected this recommendation as too costly. ${ }^{67}$

The first study of the program, conducted by the nonpartisan Employment and Training Institute of the University of Wisconsin-Milwaukee (ETI), documented the massive social service needs of those sanctioned. According to the study, 6612 Milwaukee County teens were sanctioned in the first sixteen months of full Learnfare operation, from September 1988 to December $1989 .^{68}$ Forty-one percent of children sanctioned in Milwaukee were in families having possible or documented problems with abuse or neglect or were involved in the Children's Court system, ${ }^{69}$ indicating that they had social service problems and needed major intervention through the already existing social service system. ${ }^{70}$ Only $28 \%$ of the 6612 had returned to and were regularly attending

66. Memorandum from Diane Waller, staff member of Department of Health and Social Services, to Timothy Lullen, Secretary, Department of Health and Social Services, (Nov. 24, 1987), quoted in PAWASARAT \& QUNN, supra note 53 , at 4.

67. Id. In testimony before the Senate Subcommittee on Social Security and Family Policy, the Secretary of DHSS defended the imposition of sanctions prior to providing social services to the truant teens. She used the following example:

[I]n Rock County we had an AFDC mother who until her sanction was to occur for her grant

because her son had been truant, had no idea that her young son was having problems, and was

in fact having alcohol and drug problems. And she was able to get help for him. The program

in Rock County was able to serve him and the young man is now back in school; and, of course,

the minute he went back to school there was no sanction.

Hearings, supra note 51, at 19 (testimony of Patricia A. Goodrich, Secretary, Wisconsin Department of Health and Social Services). Her example, in fact, supports exactly the opposite conclusion: there are multiple and complex reasons for truancy; the system is not effectively making parents aware when problems exist. The offer of social services without imposing the economic hardship might have solved the problem.

In spite of the documented lack of necessary social services, Governor Thompson vetoed attempts to increase the availability and accessibility of such services in the 1989-91 biennial budget. Corbett et al,, supra note 58 , at 7 .

68. PAWASARAT \& QUINN, supra note 53, at 10.

69. Id. at 15. For the first sixteen months of Learnfare, $50 \%$ of those teens sanctioned for at least ten months came from this group; $45 \%$ of the AFDC cost savings from sanctions came from this group. Id.

70. The JOBS program of the Family Support Act of 1988, Title II, Pub. L. No. 100-485, 102 Stat. 2343 (1988) requires an assessment of family circumstances and a determination of factors relevant to developing an employability plan for each participant, 45 C.F.R. $\$ 250.41$ (1991), as well as a conciliation procedure to resolve disputes regarding participation prior to sanctions. 45 C.F.R. $\$ 250.36$ (1991). These requirements were waived for 13-19 year olds under Learnfare. Letter from Tommy G. Thompson, Governor, State of Wisconsin, to Louis Sullivan, Secretary, United States Department of Health and Human Services 14-15 (Sept. 12, 1989) (on file with author) (requesting Wisconsin Learnfare waiver); Letter from Eunice S. Thomas, Acting Assistant Secretary, United States Department of Health and Human Services, to Patricia A. Goodrich, Secretary, Wisconsin Department of Health and Social Services (Dec. 29, 1989) (on file with author) (granting request). 
school two months after their last sanction. ${ }^{71}$ Moreover, the number of sanctions did not decline over the first two years of full implementation of the program. ${ }^{72}$

In short, teenagers may be unwilling to attend school for reasons including external causes such as violence in the schools, inadequate school services (e.g., special tutoring, alternative educational programs, or drug and alcohol abuse counseling), improper educational placement or assignment, the need to stay at home to babysit or care for a sick sibling. ${ }^{73}$ Learnfare makes a series of remarkable assumptions about the maturity and sophistication of teenagers, especially given behavior problems already evident through truancy. For Learnfare to succeed, teens must understand that their nonattendance at school jeopardizes their family's economic stability. They must care about family finances more than their reasons for not attending school, and they must be willing to change their behavior to retain approximately seventy-five dollars per month for Mom. ${ }^{74}$ Next, they must not be tempted to use their ability to trigger a sanction as a means to threaten and control their mothers. ${ }^{75}$ In fact, Learnfare may lead to increased family stress and create a parental incentive to kick a child out of the home if she or he fails to attend school, thus subverting the program's stated goal of furthering education for poor teens. ${ }^{76}$

71. PAWASARAT \& QUINN, supra note 53, at 10. An analysis prepared for DHSS determined that "70\% of the teens sanctioned were sanctioned for 3 months or less before meeting the Learnfare requirements." Memorandum from Silvia R. Jackson, Administrator, Division of Economic Support, to Patricia A. Goodrich, Secretary, Department of Health and Social Services (August 10,1989) (on file with author). ETI subsequently counseled against using either of these single figures to conclude too much because of data error, eligibility criteria, and lack of a control group. QUINN ET AL., supra note 51, at 5-6. Without a control group to provide a baseline of school attendance absent Learnfare, it is difficult to know whether any figure of returning students is in response to Learnfare or simply the result of normal fluctuations. Hearings, supra note 51, at 50-51 (statement of Thomas J. Corbett, Associate Scientist, Institute for Research on Poverty).

72. Learnfare Monthly Summaries, Wisconsin Department of Health and Social Services (1988-1992) (on file with author). The sanction rate declined substantially after implementation of procedural changes stipulated in Kronquist v. Goodrich, No. 89-C-1376 (E.D. Wis. July 10, 1990), but has resumed increasing. Id.

Targeted teens who were parents themselves were substantially more likely to be sanctioned than dependent teens. JOHN PAWASARAT ET aL., EMPLOYMENT AND TRAINING INSTTTUTE, UNIVERSTTY OF WISCONSIN-MILWAUKEE, EVALUATION OF THE IMPACT OF WISCONSIN'S LEARNFARE EXPERIMENT ON THE SCHOOL ATTENDANCE OF TEENAGERS RECEIVING AID TO FAMILIES WITH DEPENDENT CHILDREN 15 (Feb. 1992); QUINN ET AL, supra note 51, at 19. This fact may indicate the more complex needs and responsibilities of this group and a lesser ability of school systems to incorporate those needs and responsibilities as factors overriding the economic disincentive of Learnfare.

73. Even if one assumes strict limits and punishment are required to affect teen behavior, reducing family grant size is ineffective. Some states have responded to the truancy problem by removing an asset valued by the teen. For example, Arkansas and West Virginia have experimented with revoking the driver's licenses of teens who have dropped out of school. ARK. CODE ANN. \& 6-18-222 (Michie Supp. 1991); W. VA. CODE $\S$ 18-8-11 (1988).

74. Wisconsin's Governor Thompson, responding to critics contending his Wedfare proposal (to pay AFDC teens an extra $\$ 75$ if they got married) would encourage loveless marriages, commented: "Would you get married for $\$ 75$ a month? I don't know anybody who would be dumb enough to say, 'I'm going to get married to get an extra $\$ 75$ month."' CLASP UPDATE, supra note 8, at 8 (quoting Governor Thompson). Of course, if teens would not get married for an extra $\$ 75$ a month, Thompson's proposal would not work. Project).

75. Hearings, supra note 51 , at 55 (statement of Carol L. Croce, Executive Director, Wisconsin Nutrition

76. See THEOdore R. MARMOR ET AL., AMERICA's Misunderstood Welfare STATE 219 (1990) ("In the extreme, disincentives might be perceived as incentives, thus reversing the expected direction of 
But debates about Learnfare have generally not focused on the empirical validity of the program's underlying assumptions. As the Institute for Research on Poverty noted in criticizing the DHSS' claim of the program's success, no information exists regarding how teens with attendance problems behave in the absence of sanctions. Improved attendance (which did not ultimately result) might be the result of increased cooperation between parents and the welfare system rather than economic sanctions. ${ }^{77}$ The dramatic increase in the number of teens sanctioned as the program's first year progressed raises serious doubts about the ability of Learnfare to deter absences.

\section{B. Learnfare as a Tool for Social Contract}

The second articulated goal of Learnfare is to create a "social contract" between the government and the welfare family. ${ }^{78}$ In other words, in exchange for receiving assistance, the family must comply with certain values or modify its behavior in ways deemed appropriate by policymakers. ${ }^{79}$ Once again, this goal is predicated on faulty assumptions. The first is that welfare families are different than average families, that is, that AFDC teens are more likely to be truant than teens in non-AFDC poor families and that an AFDC mother is less responsible for her children's school attendance, less of a parent than the average parent, and does not want the best for her children. ${ }^{80}$ Another faulty assumption is that the average non-AFDC family whose child is truant is not receiving "assistance" and therefore should not be required to fulfill a "social contract" with the state. 81

Available data confirms that children in AFDC families do not miss significantly more days of school than other children. The fact that even knowledgeable policymakers such as Senator Moynihan hold the misconception that AFDC children are different from the norm was apparent in a particularly telling exchange at hearings on Learnfare before the Senate Finance Committee:

change.").

77. Memorandum from Charles Manski et al., Institute for Research on Poverty, University of WisconsinMadison, to John Antaramian, Member, Wisconsin Assembly (Sept. 1, 1989) (on file with author).

78. Compare MEAD, supra note 3, at 241-46 ("Benefits must be coupled with meaningful economic and moral obligations from recipients.") with Corbett et al., supra note 58, at 7 ("[T]he lack of services is evidence that govemment is not living up to its part of the "social contract."').

79. See 1987 Wisconsin Waiver Application, supra note 50, at 10 (explaining expectations about recipients' behavior).

80. Learnfare is seen as a way to get the attention of otherwise disinterested parents. "One way of encouraging attendance among low-income students, those who have been shown to be the most at-risk of dropping out of school is to reduce welfare benefits to parents who fail to take steps to insure that their children attend school as required by law." JOSIE FOEHRENBACH, CENTER FOR LAW AND SOCIAL POLICY, PREPARING FOR LEARNFARE: SETTING THE CONDITIONS FOR A QUESTIONABLE EXPERIMENT 2 (1988) (quoting California's Commission on Educational Quality).

81. Cf. Thomas Ross, The Rhetoric of Poverty: Their Immorality, Our Helplessness, 79 GEO. L.J. 1499, $1501(1991)$. 
Ms. BARNHART: That is, a student must have 10 unexcused absences in a semester before he/she is put on monitoring. Once they are monitored by the State, if they have two absences in a particular month, unexcused absences, at that point the sanction would be undertaken.

Senator MOYNIHAN: What is the norm for your all-American Wisconsin boy or girl? Ten is twice the average?

Ms. BARNHART: I don't know exactly what the average is, Senator. I believe the information indicates that the AFDC students, as opposed to non-AFDC students, miss about 3 days a year more than the nonAFDC students. I can tell you that relationship.

Senator MOYNIHAN: It is only 3 more days a year?

Ms. BARNHART: Roughly, I believe so.

Senator MOYNIHAN: Unbelievable.

Ms. BARNHART: I believe that's correct. One of the other people coming up later might have better information, but I think that is the case.

Senator MOYNIHAN: That is kind of important. ${ }^{82}$

Consistent with this testimony, when the Wisconsin legislature was deciding whether to expand Learnfare to cover six- to twelve-year olds, a study by the Urban Research Center of the University of Wisconsin-Milwaukee reported that "[f]or all students in grades two through five only 3 median attendance days and 3.9 mean attendance days, separate non-AFDC students from AFDC students." ${ }^{283}$ AFDC children on average attended school 169 days a year while non-AFDC children attended for 172 days. $^{84}$ This data has been consistent over many years.

Many families that have gone through a social services assessment and licensing process by the state to become foster families or family day care providers have received sanctions for their teens under Learnfare. ${ }^{85}$ The bizarre fact that families that the state has approved for child raising are later penalized by the same state for inappropriate child control highlights the irrationality of the Learnfare attendance requirements. ${ }^{86}$

AFDC mothers place a strong emphasis on education for their children. In a recent study of AFDC recipients, $82 \%$ stated that education was what it "would

82. Hearings, supra note 51, at 14 (testimony of Jo Anne B. Barnhart, Assistant Secretary for Family Support, U.S. Department of Health and Human Services).

83. WILLIAN F. MCMAHON ET AL., THE URBAN RESEARCH CENTER, UNIVERSITY OF WISCONSINMILWAUKEE, DO SCHOOL ATTENDANCE RATES VARY BETWEEN AFDC AND NON-AFDC SUPPORTED CHILDREN? 4 (1989).

84. Id. at 3 (Tables 1 and 3 ).

85. Almost $40 \%$ of the children in foster care and nearly $60 \%$ of the children in families that provide family day care were with families in which a sanction had occurred. PAWASARAT \& QUINN, supra note 53 , at 13.

86. See supra note 52 (discussing Wisconsin's decision not to impose Leamfare requirements on teens in foster care). 
take for their children to get ahead." ${ }^{.87}$ AFDC mothers agreed with both the general public and members of Congress that improvement of public schools should be either the first or second priority among mechanisms to solve poverty. ${ }^{88}$

Learnfare, however, blames the mother, assuming that she is at fault for her child's behavior, regardless of the availability of needed services. It ignores the fact that there will be some teens who will not respond to any social services or incentive (positive or negative) program and that our society already maintains a juvenile justice system to cope with these difficult teens. ${ }^{89}$ As one AFDC mother said, " $[E]$ ven probation officers can't make their clients do something if they don't want to." place her two truant teens in care of the county and "let them raise them if they think they can do better."'1

Contrast the relationship the government has with non-AFDC parents whose children are truant. Non-AFDC families receive a major tax break for each dependent; ${ }^{92}$ no one questions their continued right to receive this dependency allowance or suggests conditioning that right on the child's school attendance record. State truancy laws are enforced with wide discretion and latitude; there is certainly no automatic judicial referral after ten days absence in a semester. ${ }^{93}$ In many states, parents who are not on AFDC can be assessed only a small financial penalty for a child's truancy, and this penalty can be assessed only after a wide range of social services are provided to the truant's family ${ }^{94}$ One AFDC mother commented on the perversity of singling out poor women:

All my sons skipped school more than twice a month. Did my sons graduate? Yes. Did they get jobs? Yes. Could I keep them in school by threatening them? No. I discovered that my sons played hooky at the homes of their friends, who had employed parents and VCRs. Though their friends skipped school and harbored truants, neither they

87. FAY LOMAX COOK ET AL., CENTER FOR URBAN AFFAIRS AND POLICY RESEARCH, NORTHWESTERN UNIVERSITY, CONVERGENT PERSPECTIVES ON SOCIAL WELFARE POLICY: THE VIEWS FROM THE GENERAL PUBLIC, MEMBERS OF CONGRESS, AND AFDC RECIPIENTS $5-49$ (1988).

88. Id. at 5-55.

89. See Hearings, supra note 51, at 39 (testimony of Carol L. Croce, Executive Director, Wisconsin Nutrition Project).

90. Pat Gowens, Welfare, Learnfare-Unfair! A Letter to My Governor, MS., Sept/Oct. 1991, at 90-91.

91. Id.

92. See infra note 128.

93. In the Milwaukee public school system, only 95 of the 7,618 students identified as habitual truants in the fall semester of 1989 were referred to the District Attorney's Office. Legislative Audit Bureau Evaluation, supra note 55, at 28.

94. For example, in Massachusetts the maximum penalty is $\$ 20$, MASS. GEN. LAWs ANN. ch. $76, \S$ 3 (West 1992), as opposed to $\$ 95$ a month or $16 \%$ of the monthly AFDC grant for a family of three. In Wisconsin a parent can be referred to the district attorney for Children's Court action or criminal prosecution only after a failure to cooperate with the school's documented efforts to provide services. WIS. STAT. ANN. $\$ 118.16(5)$ (West 1991). Even then, the assistant district attorney first tries to work with the family to return the child to school, only beginning legal action when parents fail to cooperate in these efforts. Legislative Audit Bureau Evaluation, supra note 55, at 28-29. 
nor their parents suffer from the Learnfare "experiment." Class status, not truancy alone, determined who would be abused by Learnfare..$^{95}$

Not surprisingly, the recent study of the effectiveness of Learnfare by ETI ${ }^{96}$ showed no positive results, concluding that "in all six school districts the models used did not show improvement in student attendance which could be attributed to the Learnfare requirement. ${ }^{.97}$ In Milwaukee the study found that Learnfare actually increased rather than decreased absences. ${ }^{98}$

After selecting ETI as the independent evaluator, the Wisconsin DHSS cancelled ETI's contract for the final Learnfare report due June, $1993 .{ }^{99}$ DHSS Secretary Gerald Whitburn called the study the "biased product of liberal opponents of the Republican Governor."100

Even before ETI's evaluation was completed, school officials knew that Learnfare was not meeting its stated goals. ${ }^{101}$ The assistant principal of a Milwaukee high school, where more than half of the families of the 1250 students receive welfare, noted that few of the 145 sanctioned students were present on the second day of final exams, ${ }^{102}$ and Milwaukee's mayor described Learnfare as an unsuccessful experiment. ${ }^{103}$ The Milwaukee Public School Board of School Directors opposed the Learnfare Program and its expansion in its February, 1990 statement, relying on a report from the Milwaukee Public School Superintendent that concluded: "The existing Learnfare program has not been shown to be effective in returning teenagers to school; it has not increased school attendance; and it has not reduced the number of school dropouts. In addition, the number of monthly sanctions does not appear to be declining." 104

95. Gowens, supra note 90 , at 90 .

96. QUINN ET AL., supra note 51. Because the federal waiver of the demonstration project allowed Wisconsin to make all AFDC teens subject to Leamfare, thus precluding a randomly assigned control group of AFDC teens, the study was based on a lagged regression analysis which controlled for differences in age, grade level, sex, race, and months on AFDC. The control group was drawn from former AFDC teenagers and teens receiving AFDC prior, to the Learnfare experiment. PAWASARAT ET AL., supra note 72, at 3.

97. Id. at ii. Graduation rates for Milwaukee teens subject to Learnfare were the same as those for the control group-former AFDC Milwaukee teens who entered high school as freshmen in the 1987-88 school year. Id. at Il. The impact of Ohio's LEAP program on school attendance is not yet known. DAN BLOOM ET AL., LEAP: IMPLEMENTINO A WELFARE INTIATIVE TO IMPROVE SCHOOL ATTENDANCE AMONG TEENAGE PARENTS 13-14 (1991).

98. PAWASARAT ET AL., supra note 72, at 18.

99. Letter from Richard Lorang, Deputy Secretary, Wisconsin Department of Health and Social Services, to Nicholas W. Schultz, Assistant Dean, Graduate School, Employment and Training Institute, University of Wisconsin-Milwaukee (March 10, 1992) (on file with author). This cancellation followed an unsuccessful attempt by the state to revise or delay issuance of the report until state legislation on Learnfare expansion had been voted upon. Judith M. Davidoff, Learnfare: State Rips 'Bias,' Shows Own, ISTHMUS CHRON., Feb. 28,1992 at 5.

100. Lucy Howard \& Ned Zeman, Wisconsin Is Talking. . . , NEwsweEK, March 2, 1992, at 10.

101. Cf. QUINN ET AL., supra note 51, at 34 (reporting that $30 \%$ of surveyed school districts saw improved attendance, contrasted with $56 \%$ that saw "no observed change," and $20 \%$ that "observed dropouts returning to school where Learnfare or AFDC payments were identified as a reason").

102. Cooper, supra note 63 , at A3.

103. Harrison, supra note 57, at A20 (quoting John Norquist, Mayor, Milwaukee, Wis.).

104. Legislative Audit Bureau Evaluation, supra note 55, at 20. 
Learnfare's failure seriously challenges the notion that using threats to cut subsistence programs influences the behavior of those who depend on them. ${ }^{105}$ Designed to serve political rhetoric, the program was never supported by empirical data, ${ }^{106}$ but rather, was premised on superficial notions about the psychology of poor families.

\section{FAMILY CAP}

Building on the historic biases reflected in the suitable home and "man-inthe-house" rules, the Family Cap demonstration proposals attempt to influence poor women's decisions about procreation. They are inherently flawed because they are based on the assumption that the value systems of AFDC mothers are fundamentally alien to those of the rest of the population. The proposals, embraced by President Bush, eliminate or reduce additional AFDC benefits for the support of additional children conceived after a mother begins receiving AFDC. New Jersey became the first state to pursue this course of action when it enacted Family Cap legislation on January $21,1992 .{ }^{107}$ It received a federal waiver on July $20,1992 .{ }^{108}$ Wisconsin has received a waiver from HHS to operate a demonstration project for teen mothers only, ${ }^{109}$ but has not yet received state legislative authorization. ${ }^{110}$

105. Even Charles Murray has stated: "The idea that they were going to make Learnfare work is ridiculous. . . . I know I'm known for putting great stock in economic incentives, but the problem with economic incentives like this one is that if they aren't intertwined with social norms, their effect will be zip." Paul Taylor, Welfare Policy's 'New Paternalism' Uses Benefits to Alter Recipient's Behavior, WAsH. PosT, June 8, 1991, at A3 (quoting Charles Murray).

106. The Secretary of the Wisconsin DHSS reported that at the time the program was enacted, the State "did not have figures that would show ... that AFDC youngsters were dropping out ... more than non-AFDC youngsters." Hearings, supra note 51, at 18 (testimony of Patricia A. Goodrich, Secretary, Wisconsin Department of Health and Social Services).

107. Act of Jan. 21, 1992, ch. 526, 1991 N.J. Sess. Law. Serv. 526 (West). In New Jersey, mothers receive $\$ 64$ per month for the support of each additional child. 1992 GREEN BOOK, supra note 42 , at 639. Under its Family Cap statute, any AFDC recipient who has a child while eligible for AFDC would receive no additional benefits.

108. Letter from Jo Anne B. Barnhart, Assistant Secretary for Children and Families, Department of Health and Human Services, to Alan J. Gibbs, Commissioner, Department of Human Services (July 20, 1992) (on file with author).

109. According to the waiver documents, the Parental and Family Responsibility Demonstration Project (PFR) will apply to AFDC teen applicants (single or married) under age 20 who have one child or are pregnant with their first child when they enroll in PFR. The project will be implemented in as many as four counties, including Milwaukee, and is expected to become effective July 1, 1993. Under PFR, if a second child is born, the family will receive approximately one half of the current incremental amount (\$38); if a third child is born, the family will receive no additional income. Wisconsin Department of Health and Social Services, Parental and Family Responsibility Demonstration Project, Waiver Application to U.S Department of Health and Human Services 2, 11-12, 18-19 (Mar. 13, 1992) (on file with author) [hereinafter 1992 Wisconsin Waiver Application].

110. The Wisconsin Legislature passed a bill authorizing two other initiatives of the Parental Responsibility Program but not the Family Cap. Enrolled 1991 Assembly Bill 91 (Wis.) $\$ 1479$. Governor Thompson, however, vetoed the substance of the bill, retaining only the language authorizing the DHSS to seek a federal waiver for an unspecified parental responsibility pilot project. 1991 Wis. Legis. Serv. 39 (West). In his veto message, Governor Thompson stated that he would do his "utmost to see to it that this important program receives a federal waiver and is implemented in Wisconsin." Governor's Message Vetoing 
Wisconsin offered two reasons for testing a Family Cap Program: (1) to reduce long-term welfare dependency among families headed by male and female teen parents; ${ }^{111}$ and (2) to delay subsequent births to first-time teen parents who receive AFDC until they are emotionally and financially prepared to support additional children. ${ }^{112}$ The New Jersey proposal applies to all AFDC mothers regardless of age; its goal is a more extensive effort at "mutual responsibility." 113 The proposal contends that "welfare recipients will be asked to make the same type of decisions based on their income that working families have to make about supporting their family based on the money they earn."114 The underlying goal of Family Cap programs is for people to plan for their children; the assumption is that middle-class people are intelligent enough to refrain from having children when they cannot support them and that poor women should do likewise. The unspoken motivation is far less racially benign: the stereotypical AFDC mother is African American, urban, lazy, and a "bad mother" who gets pregnant to obtain more AFDC benefits. It follows, according to the argument, that the denial of these additional benefits will curb the pregnancies that the policymakers find so troubling.

As was the case with the Learnfare programs, the underlying assumptions of Family Cap proposals - that AFDC mothers have many children, that they have free access to medical options for family planning, and that they get pregnant in order to receive additional benefits - are unsound. In fact, as of 1990, the average AFDC family, including adults, had 2.9 members; $72.5 \%$ of all families on AFDC had only one or two children, and almost $90 \%$ had three or fewer children. ${ }^{115}$ These figures are no larger than those found among two-

Enrolled 1991 Assembly Bill 91 (Aug. 8, 1991), reprinted in 1991 Wis. Laws 39.

111. A high correlation exists between teen childbearing and receipt of AFDC. Nearly $50 \%$ of all adolescent mothers and over 75\% of unmarried teen mothers receive AFDC within five years of giving birth. CONGRESSIONAL BUDGET OFFICE, CONGRESS OF THE UNITED STATES, SOURCES OF SUPPORT FOR ADOLESCENT MOTHERS xvi (1990). Evaluations of the total length of time on AFDC vary depending on the time standards used. Compare id. (reporting that almost $50 \%$ of adolescent mothers who receive AFDC stop getting benefits for at least three months within one year, and almost 75\% leave AFDC within three years) with Greg J. Duncan et al., Welfare Dependence Within and Across Generations, ScIENCE, Jan. 29, 1988, at 467, 468 (asserting that more than $40 \%$ of never-married women with young children who began receiving AFDC when they were under 25 years continue to receive it for more than nine years).

112. 1992 Wisconsin Waiver Application, supra note 109, at 1.

113. New Jersey Department of Human Services, Family Development Program, Waiver Application to U.S. Department of Health and Human Services 25 (June 5, 1992) (on file with author) [hereinafter 1992 New Jersey Waiver Application].

114. Id. Because the New Jersey Family Cap proposal is part of a broader Family Development Program that includes an increased earnings disregard, the program "is based on the same principle that applies to everyone else in our society. If a person is working and has a baby, that person's salary is not automatically increased. ... We believe that if a person is given a choice, that person will do what is best for the family which, in this case, is work." Id. at 8 . This comment reveals another underlying assumption of the New Jersey program - that AFDC mothers do not work because they can receive AFDC benefits. The relationship between work and welfare is a topic that has engendered a great deal of commentary and is beyond the scope of this Essay. See, e.g., ELLWOOD, supra note 38, at 137-55 (suggesting that current work-welfare programs do little to solve poverty and welfare struggles that single mothers face).

115. 1992 GREEN BOOK, supra note 42, at 669. 
parent families in the general population. ${ }^{116}$ Moreover, AFDC family size has declined substantially; in $1969,32.5 \%$ of AFDC families had four or more children, and in 1990 , only $9.9 \%$ had four or more children. ${ }^{117}$ Contrary to the commonly held perception that teen pregnancies are skyrocketing, teen birthrates have dropped dramatically over the last three decades. ${ }^{118}$

Furthermore, for those women who wish to terminate their pregnancies, neither abortion facilities nor government funding are necessarily available. ${ }^{119}$ Title X of the Public Health Service Act, the only federal program targeted for the provision of family planning services, was cut by $16 \%$ during the 1980 's. ${ }^{120}$ In addition, even when a woman does obtain birth control, the failure rates for the most reliable forms of contraceptives (i.e., the pill, diaphragms, condoms) range from $6 \%$ to $16 \%$ per year. ${ }^{121}$

There are many reasons why AFDC mothers become pregnant or choose to remain pregnant. These reasons include occurrences of unplanned pregnancies (whether due to a lack of information, money, or forethought), the belief that a child solidifies a relationship with the father, ${ }^{122}$ the assumption that children

116. Of all U.S. families, married couples with children under age 18 have an average of 1.88 children each. BUREAU OF THE CENSUS, U.S. DEPARTMENT OF COMMERCE, CURRENT POPULATION REPORTS, HOUSEHOLD AND FAMILY CHARACTERISTICS: MARCH 1991 (1992). In fact, the birth rate of AFDC mothers in Wisconsin is 39\% lower than the rates for the general population. Furthermore, the longer a woman remains on welfare, the less likely she is to give birth. See Mark R. Rank, Fertility Among Women On Welfare: Incidence and Determinants, 54 AM. Soc. REV. 296, 301 (1989).

117. 1992 GREEN BOOK, supra note 42, at 669. The Director of Maine's Bureau of Income Maintenance, citing a 20 year review of state data showing a substantive decrease in AFDC family size, resigned rather than support the Maine Govemor's Family Cap proposal. Sabra Burdick, Statement on Resigning as Director, Bureau of Income Maintenance, Maine (Feb. 5, 1992), quoted in CLASP STATES NETWORK UPDATE (Center for Law and Social Policy, Washington, D.C.), Feb. 19, 1992, at 11 [hereinafter FEB. CLASP UPDATE].

118. The teen birthrate per 1000 females aged $15-19$ was 89.1 in $1960,68.3$ in 1970 , and 58.1 in 1989 . 1992 GREEN BOOK, supra note 42, at 1093; CHIID TRENDS, INC., FACTS AT A GLANCE 1 (Jan. 1992). Although the birth rate for African-American teens has always been higher than for white teens, the Birth Rate for African-American teens has fallen with some fluctuation over the longterm, from 156.1 births per 1000 in 1960 to 115.0 births in 1989.1992 GREEN BOOK, supra note 42, at 1098. Further, although pregnancy rates for white women have been increasing since 1986 and for African-American women since 1984, id. at 1093, this rise cannot be credited to an increase in the economic incentive of AFDC benefits, since the value of AFDC benefits has been substantially declining since 1972. The average monthly payment per recipient in 1972 was $\$ 170.32$ in 1990 dollars, but only $\$ 136$ in 1990. U.S. DEPARTMENT OF HEALTH AND HUMAN SERVICES, SOCIAL SECURTTY ADMINISTRATION, SOCIAL SECURTY BULLETIN, ANNUAL STATISTICAL SUPPLEMENT 108 (1992) [hereinafter SOCLAL SECURTY BULLETIN].

119. This Essay does not detail the complexities of Medicaid abortion funding. Suffice it to say that the Supreme Court has held that the Constitution does not require the government to finance abortions. Harris v. McRae, 448 U.S. 297, 326 (1980); Maher v. Roe, 432 U.S. 464, 469 (1977). Some state courts, however, have construed their state constitutions to the contrary. See Judith O. Brown et al., The Failure of Gender Equality: An Essay in Constitutional Dissonance, 36 BUFF. L. REV. 573, 637 (1987) (collecting cases).

120. Ross Danielson et al., Title $X$ and Family Planning Services for Men, 20 FAM. PLAN. PERSP. 234, 234 (1988). But see KRISTIN A. MOORE, THE URBAN INSTITUTE, POLICY DETERMINANTS OF TEENAGE CHILDBEARING 63 (1980) (listing studies that document importance of family planning services to reduce low-income teen pregnancy, but finding measures of family planning availability not associated with lower levels of fertility).

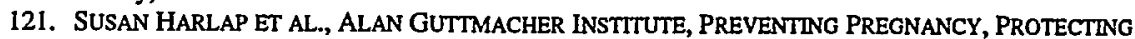
HEALTH: A NEW LOOR AT BIRTH CONTROL CHOICES IN THE UNITED STATES 120 (1991).

122. ELDAH ANDERSON, STREETWISE 119 (1990). If this is the motivation, then a much stronger economic incentive, such as the earnings of the man, must be factored in. 
represent an economic value (e.g., to serve as agricultural workers, to support parents in their old age), ${ }^{123}$ the belief that the significant health problems and infant mortality rates associated with poverty increase the risk that a single woman with only one child will become childless, ${ }^{124}$ a sense that one's life is so hopeless that having a child gives it value and meaning, ${ }^{125}$ and the desire to give a grandchild to one's own mother. ${ }^{126}$ Many of these reasons are equally applicable to non-AFDC, middle-class women.

"Normal" women allegedly have children only when they are economically able to support them. ${ }^{127}$ This is not true. Most people do not view having a baby as the prize for having made it economically, nor do they have a child to gain an additional tax deduction for a dependent. ${ }^{128}$ Just like AFDC recipients, they want to be parents and to share their lives with a child. ${ }^{129}$ Of course, some families decide not to have an additional child because they believe that they cannot afford it, but the dollar value placed on whether they can afford it varies widely. Therefore, many upper-income families may have a small number of children because they believe it is critical to provide the child with certain advantages, such as piano lessons or private school education, that never enter the minds of a working class family with more children.

Empirical studies have consistently documented the lack of a correlation between the receipt of AFDC benefits and the child-bearing decisions of unmarried women-even for young, unmarried women. ${ }^{130}$ In a recent study

123. Cf. Albert A. Fitzpatrick, The Estate Value of a Child, 25 J. FAM. L. 529, 531 (1987) (discussing economic value of children in context of childbearing costs).

124. NATIONAL COMM'N TO PREVENT INFANT MORTALITY, TROUBLING TRENDS PERSIST: SHORTCHANGING AMERICA's NEXT GENERATION viii-ix, 17 (1992).

125. Given the correlation between lack of literacy skills, teen pregnancy, and long-term welfare use, a focus on improved school districts, remedial education, and specially tailored programs that provide these teens (before or after becoming mothers) with basic skills is a critical link to reducing teen pregnancy. CHILDREN'S DEFENSE FUND, ADOLESCENT PREGNANCY PREVENTION CLEARINGHOUSE, MODEL PROGRAMS: PREVENTING ADOLESCENT PREGNANCY AND BUILDING YOUTH SELF-SUFFICENCY 14-15 (1986) [hereinafter PREVENTING ADOLESCENT PREGNANCY].

126. MOORE, supra note 120, at 5; PREVENTING ADOLESCENT PREGNANCY, supra note 125, at 3-4 (discussing lack of both self-esteem and sex education as significant factors contributing to increased teen pregnancy).

127. Ellen Goodman, Welfare Mothers With an Attitude, BOSTON GLOBE, Apr. 16, 1992, at 19.

128. Such an analysis ignores that when another child is born into a "working" family, the "benefit" received through a federal tax deduction is higher in actual dollars than the incremental amount received by an AFDC recipient in most states. For example, a married couple with one child and income up to $\$ 48,700$ in 1992 receives a federal tax savings of $\$ 345$ per year for an additional child; a married couple with one child and income between $\$ 48,700$ and $\$ 99,450$ receives a federal tax savings of $\$ 645$ a year for an additional child. CENTER ON BUDGET AND POLICY PRIORITIES ET AL, SELECTED BACKGROUND MATERIAL ON WELFARE PROGRAMS, FAMILY CAP PROPOSALS WILl NOT PREVENT PREGNANCY BUT WILL HARM FAMILIES 2 (Feb. 21, 1992). See also Ross, supra note 81 , at 1520 (speculating that if states were to defend federal ceiling on number of dependents that could be claimed for tax purposes as rationally providing family planning incentives, public outcry would be far more persuasive and impassioned than it has been against family planning proposals for "morally weak" poor).

129. Even among the general population, studies demonstrate that $37 \%$ of all births are unintended. Jacqueline D. Forrest, Unintended Pregnancy Among American Women, 19 FAM. PLAN. PERSP. 76 (1987).

130. MOORE, supra note 120, at 62; The Effect of Government Policies on Out-of-Wedlock Sex and Pregnancy, 9 FAM. PLAN. PERSP. 164 (1977). See also WILlIAM JULIUS WILSON, THE TRULY DisadVANTAGED 78-81 (1987). But see Robert D. Plotnick, Welfare and Out-of-Wedlock Childbearing: Evidence from 
of AFDC recipients by the Center for Urban Affairs and Policy Research, $100 \%$ of the mothers said their ability to receive AFDC had no effect on the decision to have a child. ${ }^{131}$ In addition, AFDC families are not larger in those states with larger AFDC grants, ${ }^{132}$ and teen birth rates are not higher in the states with higher AFDC grants. ${ }^{133}$ The number of female-headed families has continued to grow since the early 1970's, even though AFDC benefits, adjusted for inflation, have decreased by $30 \% .{ }^{134}$ Women receiving AFDC are less likely than non-AFDC recipients to want an additional child, ${ }^{135}$ less likely to have multiple pregnancies, and more likely to practice contraception. ${ }^{136}$

Furthermore, the incremental increase that an AFDC family receives when a new child enters the family is so small that it does not even cover such basic essentials as diapers, clothing, bottles and formula. In Wisconsin, for example, an additional third child adds $\$ 100$ to the grant; in New Jersey, $\$ 64$; in Mississippi, $\$ 24{ }^{137}$ Thus if economics were really the driving factor in an AFDC mother's decision to have a child, she would make the "rational" decision not to do so.

If Mississippi's economic disincentive of giving only an additional \$24 for another child has not reduced AFDC family size or curbed teenage birth rate, Wisconsin's reducing the grant increment from $\$ 77$ to $\$ 39$ is also likely to be ineffective. ${ }^{138}$ If poor people do not change their behavior based on the

the 1980s, 52 J. MARRIAGE \& FAM. 735 (1990). This is an excellent example of how the scope of the inquiry defines the debate; by focusing on whether AFDC fosters pregnancy, discussion is diverted from true solutions for teenage pregnancy.

131. COOK ET AL., supra note 87 , at 5-40.

I didn't decide Ito have a baby]. I didn't know anything about babies at the time. I wanted to

be with [my boyfriend]. . . . My mom said no. I snuck out and saw him anyway and BINGO!

I got pregnant. I had my cake and had to eat it too.

Id. at 5-40 (quoting unnamed AFDC recipient).

132. Mississippi, the state with the highest percentage of families with four or more children, has the lowest AFDC grant level of any state in the country and only increases the grant level by $\$ 24$ for each additional child. Conversely, Maine and Vermont, the two states with the lowest percentage of families with four or more children, have AFDC grant levels well above the national median. FAMILY SUPPORT ADMINISTRATION, U.S. DEPARTMENT OF HEALTH \& HUMAN SERVICES, 1989 AFDC RECIPIENT CHARACTERISTICS STUDY 24 (Table 6) (1991); 1992 GREEN BOOK, supra note 42, at 638-39.

133. The five states with the highest teen birth rates for 18-19 year olds (Arizona, Arkansas, Mississippi, Nevada, and New Mexico) all have AFDC benefits below the national median; the five states with the lowest 18-19 year old teen birth rates (Massachusetts, Minnesota, New Hampshire, North Dakota, and Vermont) all have AFDC benefits above the national median. CHILD TRENDS, INC., supra note 118, at 5 (Table 2); SOCIAL SECURTTY BULLETIN, supra note 118, at 306.

134. ELLwOOD, supra note 38 , at 59-61, 77.

135. In a study of New York mothers who recently had their first child, AFDC recipients desired fewer children than other recent first-time mothers. Hariet B. Presser \& Linda S. Salsberg, Public Assistance and Early Family Formation: Is there a Pronatalist Effect?, 23 SOC. PROB. 226, 230-31 (1975). African-American AFDC recipients who were unmarried at the time they had their first child likewise did not desire more children than did African-American non-AFDC recipients. Id. at 233.

136. Paul J. Placek \& Gerry E. Hendershot, Public Welfare and Family Planning: An Empirical Study of the "Brood Sow" Myth, 21 SOC. PROB. 658, 666, 668 (1974).

137. 1992 GREEN BOOK, supra note 42 , at 638-39.

138. MARK GREENBERG, CENTER FOR LAW AND SOCIAL POLICY, WISCONSIN'S TEEN WELFARE WAIVER: AN ANALYSIS OF THE PARENTAL AND FAMIIY RESPONSIBILITY DEMONSTRATION PROJECT 4 (1992). 
strongest economic motivator-living well below the poverty level ${ }^{139}$ - the additional economic incentive of a $\$ 70$ AFDC reduction is certainly nondeterminative. ${ }^{140}$

\section{THE METHOD BeHIND THE MADNESS}

In the face of uniform data that Learnfare, Family Cap, and other behavioral modification "welfare reform" proposals will not accomplish their articulated goals, why do policymakers, politicians, and the American public continue to espouse and support them ${ }^{141}$ Why does American society cling to the myth that unlike the majority, welfare recipients have deviant values that can be manipulated solely by the economics of a meager AFDC grant? ${ }^{142}$ What has changed since the passage of the Social Security Act during the New Deal? Have those changes affected our historical ambivalence toward and perceptions of poor women and children? The answer to these questions lies in a New Right agenda, ${ }^{143}$ which I call an ideology of division, playing to America's deepest racial fears and to resentment of the poor, single, unemployed mother. ${ }^{144}$

Beginning in the early 1980's, the New Right's economic strategy was to privilege the rich, thereby causing the "trickle down" of largesse from the wealthy to the poor. The articulated ideology was that by investing, the wealthy would create opportunities for those less fortunate. ${ }^{145}$ However, the result of supply-side economics has been redistribution of money to the rich, increased poverty, and a decline of the buying power of wages. ${ }^{146}$ To legitimate the

139. Ross, supra note 81 , at 1510 .

140. See MARMOR ET AL., supra note 76, at 219-22 (discussing limits of economic incentives for behavioral change).

141. A recent Califomia poll conducted by the Field Institute found that $87 \%$ of respondents favored Govemor Pete Wilson's Learnfare proposal (10\% opposed) and 58\% favored his Family Cap proposal (37\% opposed). Vlae Kershner, Californians Split Over Governor's Welfare Plan, S.F. CHRON., Feb. 4, 1992, at Al. A poll of Milwaukee County residents found that $70 \%$ supported reducing grants to welfare families whose children skip school. Paul Taylor, Debating The Lesson of Learnfare: Does Cutting Welfare Reduce Truancy?, WASH. POST, Feb. 19, 1992, at A17.

142. In 1971, a poll found that $63 \%$ of Americans strongly agreed or tended to agree that unmarried women on welfare had babies to increase their AFDC grants. Opinion Research Corporation Survey, May 25,1971 , available in DIALOG, File No. 468. In 1985, a public opinion poll found that $48 \%$ of Americans nationwide believed that poor women get pregnant in order to receive AFDC. I. A. Lewis \& William Schneider, Hard Times: The Public On Poverty, PUB. OPINION, June/July 1985, at 2, 7.

143. The conservative Manhattan Institute financially supported the writing of Gilder's Wealth and Poverty and Murray's Losing Ground. It hired someone to run the "Murray campaign," spent $\$ 15,000$ to send 700 free copies of the book to "influential politicians, academics, and journalists," booked Murray on talk shows, and organized a seminar "with intellectuals and journalists influential in policy circles." KATZ, supra note 12, at 152; FRED BLOCK ET AL., THE MEAN SEASON: THE ATTACK ON THE WELFARE STATE 51 (1987).

144. See, e.g., GILDER, supra note 5, at 135; MURRAY, supra note 5, at 126-27, 133.

145. GILDER, supra note 5, at 67.

146. KEVIN PHILLIPS, THE POLITICS OF RICH AND POOR 8-23 (1990). In 1974, 11.4\% of year-round, full-time workers had low annual earnings $(\$ 4,843 / \mathrm{yr}$, or $\$ 2.42 / \mathrm{hr})$; in 1990 , that number, when adjusted for inflation, rose to $17.8 \%$. BUREAU OF THE CENSUS, U.S. DEPARTMENT OF COMMERCE, CURRENT POPULATION REPORTS, CONSUMER INCOME, SERIES P-60, NO. 178, WORKERS WTTH LOW EARNINGS: 1964 TO 1990, 4 (1992) [hereinafter WORKERS WITH LOW EARNINGS]. In 1990, 17.1\% of the U.S. population 
failure of their economic agenda, the New Right sought to divert workers' justified anger from the wealthy and to focus it on welfare recipients, those who, it was argued, had not seized the offered opportunity, did not share the national work ethic, and whose values seemed to deviate dramatically from the national ideology. ${ }^{147}$

The articulation of the "otherness" 148 of the poor-their amorality and depravity - is longstanding. ${ }^{149}$ But the unique contribution of the American New Right has been to manipulate public attitudes through the subtle use of racism, scapegoating and stereotypes. It is no accident that the bulk of conservative scholarship about public assistance has focused on AFDC, the social welfare program that highlights most graphically race and gender distinctions. ${ }^{150}$ Thus the New Right has achieved popular acceptance for the misuse of AFDC laws, ${ }^{151}$ shifting our attention from national structural problems to the purported social deviance of individual women of color. ${ }^{152}$

eamed less than half the median income, up from $12.5 \%$ in 1970 . MichAEL WOLFF ET AL., WHERE WE STAND 23 (1992). Of U.S. families, 5.4\% had a total income of over $\$ 100,000$ in 1990 , up from $2.4 \%$ in 1970 (1990 dollars). At the other end of the income spectrum, 3.6\% of families had incomes under $\$ 5,000$ in 1990, up from $2.4 \%$ in 1970 (1990 dollars). BUREAU OF THE CENSUS, U.S. DEPARTMENT OF COMMERCE, CURRENT POPULATION REPORTS, CONSUMER INCOME SERIES P-60, NO. 174, MONEY INCOME OF HOUSEHOLDS, FAMILIES, AND PERSONS IN THE UNITED STATES: 1990, 199 (1991). The median income of families with a family head younger than 30 dropped $32.1 \%$ between 1973 and 1990 . CHLDREN's DEFENSE FUND \& NORTHEASTERN UNIVERSITY'S CENTER FOR LABOR MARKET STUDIES, VANISHING DREAMS: THE ECONOMIC PLIGHT OF AMERICA'S YOUNG FAMIIIES 6 (1992).

147. See GILDER, supra note 5, at 45. See also MEAD, supra note 3, at 65-66; LAWRENCE M. MEAD, THE NEW POLITICS OF POVERTY: THE NONWORKING POOR IN AMERICA 49-52 (1992) [hereinafter MEAD, NONWORKING POOR].

148. Feminist theory provides a powerful critique of the idea that the "other" is less worthy. See, e.g., MARTHA MNOW, MAKING ALL THE DIFFERENCE: INCLUSION, EXCLUSION, AND AMERICAN LAW (1990); DEBORAH L. RHODE, JUSTICE AND GENDER (1989).

149. See Ross, supra note 81 , at 1502-08 (documenting historical consistency of society's depiction of poor as socially deviant or patently immoral).

150. See GLDER, supra note 5, at 114-27, 132-41; MEAD, NONWORKING POOR, supra note 147, at 53-54, 79-80, 83, 116-19; MURRAY, supra note 5, at 61, 157-66. Public assistance for the elderly or the disabled, although far more costly, is far less threatening. KATZ, supra note 12, at 231; SOCIAL SECURITY BULLETIN, supra note 118, at 101-102. Opinion polls routinely show support for social security: in 1983, only $8 \%$ of those surveyed thought Social Security benefits were too high; in 1984, 88\% supported maintaining cost-of-living increases for Social Security. Gallup Poll, Oct. 1984, available in DIALOG, File No. 468; ABC News/Washington Post Poll, Jan. 1983, available in DIALOG, File No. 468.

151. Many of the current behavior modification proposals are specifically linked with and lobbied for by conservative think tanks such as the Heritage Foundation. E.g., Robert Rector, Strategies for Welfare Reform, testimony before the Domestic Task Force of the Select Committee on Hunger, U.S. House of Representatives, Apr. 9, 1992, reprinted in 378 THE HERITAGE LECTURES, at 10.

152. The AFDC cuts that are publicly supported are those that address behavioral modification and values. See supra note 141. The same poll that showed support for Learnfare and Family Cap indicated opposition to direct cuts in AFDC grants. Kershner, supra note 141, at A1. See 1992 Yankelovich Clancy Shulman Poll, May 15, 1992, available in DIALOG, File No. 468 (showing 75\% of respondents oppose cutting amount of money given to people on welfare); see also COOK ET AL, supra note 87, at (Table 3-1) ( $84.5 \%$ of respondents state AFDC should be maintained or increased). Polls consistently show support for helping the "needy" and "assistance to the poor." BLOCK ET AL., supra note 143, at 46-47; 1991 National Opinion Research Center Poll, Sept. 1991, available in DIALOG, File No. 468. In fact, it has been suggested that in some cases the behavioral modification proposals are merely a smoke screen to divert attention from the more significant cuts in AFDC grant levels. FEB. CLASP UPDATE, supra note 117, at 8. 
In the current variation of "otherness," the average citizen considers all AFDC recipients as part of the "underclass,"153 i.e., African-American, longterm welfare recipients who live in inner-city ghettos and regularly have babies. ${ }^{154}$ The stereotype also holds that unlike whites, these undeserving poor have warped values, ${ }^{155}$ which do not include the desire for such things as good schools, jobs, or safe streets. ${ }^{156}$ The Los Angeles riots confirmed the deep belief of white Americans that the underclass of color is not only permanent, but determined to undermine white, middle-class ways of life ${ }^{157}$ Consequently, the current "welfare reform" proposals are designed to "re-exclude" these "undeserving" poor, until they modify their behavior and prove they are worthy of our largesse. ${ }^{158}$

The New Right's success in drawing support from working and middle class whites indicates the depth and pervasiveness of the myth of deviance regarding the AFDC African-American underclass. ${ }^{159}$ By exploiting a stereotype based on race and demerit, the New Right encourages the average white citizen to distance herself or himself from the African-American welfare mother and her children. ${ }^{160}$ While a white may support income transfer programs for the elderly because she or he anticipates growing old someday, ${ }^{161}$ whites know that they will never be African American, fourteen years old and pregnant. They

153. Given the well-documented crisis of some urban poverty communities, CHRISTOPHER JENCKS, RETHINKING SOCIAL POLICY (1992); THE URBAN UNDERCLASS (Christopher Jencks \& Paul E. Peterson eds., 1991), a comprehensive targeted policy that addresses the serious problems facing the population encompassed in the term "underclass" is essential. However, these communities are not comprised primarily of AFDC recipients. Rather, a major group with critical needs is African-American male youth, not AFDC recipients. William Julius Wilson \& Kathryn M. Neckerman, Poverty and Family Structure: The Widening Gap between Evidence and Public Policy Issues, in FIGHTING POVERTY, WHAT WORKS AND WHAT DOESN'T 232, 252-56 (Sheldon H. Danziger \& Daniel H. Weinberg eds., 1986). It is ludicrous to articulate AFDC behavioral modification eligibility changes as a means of fixing these problems. See MARMOR ET AL., supra note 76, at 119-24 (discussing how Family Support Act would not substantially affect conditions of underclass).

154. RUTH SIDEL, WOMEN AND CHILDREN LAST: THE PLIGHT OF POOR WOMEN IN AFFLUENT AMERICA 11 (1986).

155. A 1990 study showed that $62 \%$ of whites thought African Americans tended to be lazy, while 54\% thought Hispanics likely to be lazy. Seventy-eight percent thought African Americans and 72\% thought Hispanics preferred to live off welfare. TOM W. SMITH, NATIONAL OPINION RESEARCH CENTER, UNIVERSITY OF CHICAGo, ETHNIC IMAGES 9 (1990).

156. The historical underpinnings and fallacy of the association of the African American with a "culture of poverty" are comprehensively examined in JACQUELINE JONES, THE DISPOSSESSED (1992).

157. See generally ANDREW HACKER, Two NATIONS: BLACK AND WHTTE, SEPARATE, HOSTILE, UNEQUAL 187-88 (suggesting that whites regard crimes committed by African Americans as forms of resistance and retribution).

158. See Handler, supra note 13 , at 460 .

159. See id. at 523 (arguing that certain welfare reformers create images of the "unworthy" AfricanAmerican welfare dependent to impose harsh, stigmatizing welfare programs); see also Hearings, supra note 51, at 49 (statement of Thomas J. Corbett, Associate Scientist, Institute for Research on Poverty) (arguing that powerful images of underclass are pushing welfare reform back into "changing people").

160. See generally MARMOR ET AL., supra note 76, at 7 (discussing how American social myth of rugged individualism creates negative attitude toward welfare dependency).

161. The rhetoric of helplessness as to how to solve the poverty of women and children, see Ross, supra note 81 , at 1509-10, is not present in our discussions regarding the elderly, among whom we have substantiaily reduced the poverty rate through income transfer programs. JONES, supra note 156, at 272; PHILLIPS, supra note 146, at 203-07. 
can freely discount poverty as the moral failing of urban African-American culture, rather than recognizing it as a social condition cutting across racial and geographic lines and entrapping even the morally virtuous. The myth enables whites to nourish their deeply held belief that they will never be poor because they work hard, keep their kids in school, and make rational family planning decisions. ${ }^{162}$

Contrary to the myth, empirical data does not support the stereotype of welfare recipients as African Americans living in urban ghettos. Only 39.7\% of all AFDC recipients in 1990 were African American. ${ }^{163}$ Non-Hispanic whites comprised $38.1 \%$ of AFDC recipients in 1990. The percentage of AfricanAmerican recipients has in fact decreased from $45.8 \%$ since $1973 .{ }^{164}$ Moreover, only $8.9 \%$ of the total poor live in "ghettos." 165 The median stay on AFDC in 1990 was twenty-three months. ${ }^{166}$ Under any of the prevailing definitions, the urban "underclass" is but a small percentage of the AFDC population. ${ }^{167}$

Nevertheless, by focusing on images of the underclass welfare mother, the New Right has reduced the entire poverty debate to the AFDC program. The New Right advocates have transformed the increase of minorities on AFDC rolls in the 1960's and 1970's into a racially dependent definition of poverty. ${ }^{168}$ The New Right inflames outrage at the lack of individual responsibility in the African-American community, thus making it acceptable to express blatantly racist concepts without fear or shame. ${ }^{169}$

The New Right has played not only to racial fears and prejudice, but also to the dream of intact families and the fantasy of women as moral guardians. ${ }^{170}$

162. See Ross, supra note 81 , at $1500-01$.

163. 1992 GREEN BOOK, supra note 42 , at 670 . In Wisconsin, $48 \%$ of families in which a teen was subject to Learnfare were headed by a white parent and $34 \%$ were headed by an African-American parent. QUINN ET AL., supra note 51 , at 9.

164. 1992 GREEN BOOK, supra note 42 , at 670.

165. THE URBAN UNDERCLASS, supra note 153, at 251 (defining "ghetto" as metropolitan census tract having poverty rate above $40 \%$ ).

166. 1992 GREEN BOOK, supra note 42 , at 670.

167. See KEN AULETTA, THE UNDERCLASS xvi (1982) (describing "underclass" as connected with behavioral and moral deficiencies). The exact parameters and size of this subpopulation vary widely. Ricketts and Sawhill summarize selected studies on the underclass which use different definitions of the term "underclass." The study with the broadest definition (people poor at least five years between 1967 and 1973) found the underclass to make up 5.3\% of the U.S. population. A 1979 study using the more generally accepted definition of the underclass, encompassing all people living in census tracts with poverty rates above $40 \%$, estimated the underclass at only $0.8 \%$ of the U.S. population. Long-term AFDC recipients living in poverty areas comprised only $2.9 \%$ of the U.S. poverty population and $0.4 \%$ of the U.S. population. Erol R. Ricketts \& Isabel V. Sawhill, Defining and Measuring the Underclass, 7 J. POL'Y ANALYSIS \& MGMT. 316, 319 (1988).

168. See, e.g., MURRAY, supra note 5, at 54 ("The customary-indeed, virtually the only practicable-way to deal with this problem is by using a racial breakdown, namely by comparing the trendline among blacks with the trendline among whites.").

169. See, e.g., Handler, supra note 13 , at 460 .

170. See, e.g., GILDER, supra note 5, at 70-71; ROTHMAN, supra note 32 , at 26 . Also key to the New Right's embracing of behavior modification welfare proposals is its philosophical opposition to all govemment programs for the poor, perceived as contrary to pro-family, anti-divorce values. GLLDE, supra note 5, at 117; MURRAY, supra note 5, at 277-78; "[M]arriage is probably the best anti-poverty program of all." Dan Quayle, Murphy Brown and the Media Elite: Moral Poverty, CRISIS, July/Aug. 1992, at 45. "Indeed, after 
In the New Right mythology, single mothers, particularly those not economically "independent," are necessarily sexually overactive and morally deviant. ${ }^{171}$ This gender bias, like racial stereotyping, is not new to the welfare debate. Our social welfare policy has always preferred white women who were related to a man in the labor market or were in the workforce themselves. ${ }^{172}$

The demographics of the labor market, however, have changed. Since the early 1970's, as real wages fell and as buying power declined, women have entered the workplace in unprecedented numbers. ${ }^{173}$ They went to work outside the home not only because the women's movement opened some previously closed doors, but also because of the belief that two incomes were necessary to maintain a desired lifestyle. ${ }^{174}$

A growing number of women now would prefer not to work, but feel trapped by perceived economic circumstances. ${ }^{175}$ Social expectations about women as domestic caretakers have not adjusted to the realities of working women. Women are still expected to do the bulk of the child care, home care, and nurturing, and they are often overwhelmed by the substantial and conflicting demands on their time. ${ }^{176}$

work the second principle of upward mobility is the maintenance of monogamous marriage and family." GILDER, supra note 5, at 69.

171. See THE InSTITUTE for CUltural CONSERVATISM, CUltural CONSERVATISM: TOWARD a NEW NATIONAL AGENDA 83 (1987) (discussing "culture of instant sensual gratification"); Martha Albertson Fineman, Intimacy Outside The Natural Family: The Limits Of Privacy, 23 CoNN. L. REv. 955, 958 (1991). But it is still the male model of being tied to the labor market that creates one's lack of "dependency." Fathers who "depend" on women's unpaid labor to raise children and care for the home are not "dependent." Few would stigmatize at-home wives as "dependent" on their husbands, since the family unit is intact and a working role model is in the home. See ELLWOOD, supra note 38, at 135. Moreover, a woman with children whose benefits derive from a deceased or disabled man's Social Security earnings record is not considered "dependent," although in every other respect she may look identical to the AFDC mother. HACKER, supra note 157 , at $91-92$.

172. See Martha L. Fineman, Images Of Mothers In Poverty Discourses, 1991 DUKE L. J. 274, 280-81 (1991); Handler, supra note 13, at 487, 522.

173. The number of women working outside the home increased 88\% between 1964 and 1989: from $32,441,000$ to $61,116,000$. WORKERS WITH LOW EARNINGS, supra note 146, at 1 . Of women with children under the age of six, $64 \%$ worked at some time during the year, although only $25 \%$ worked full-time yearround. U.S. GENERAL ACCOUNTING OFFICE, MOTHER-ONLY FAMILIES: LOW EARNINGS WLL KEEP MANY CHLDREN IN POVERTY 4 (1991).

174. See BARBARA R. BERGMANN, THE ECONOMC EMERGENCE OF WOMEN 29-34 (1986); ElLWOOD, supra note 38 , at 65 . While in 1980 , only $19 \%$ of women working outside the home said employment was necessary to support their families and $43 \%$ said they worked to earn "extra" money, in 1990,31\% said they worked to support their families and only $32 \%$ said they worked to bring home extra money. Tense Times for Families, THE PUBLIC PULSE (Roper Org., Inc.), Jan. 1991 [hereinafter Tense Times].

175. A 1990 poll found that $43 \%$ of women aged $21-29$ would give up work indefinitely if they could afford the income loss. This is an increase of 9\% since 1989. Helaine Olen, Boomer Backlash: Women Say They'll Put Family First, L.A. TMES, June 12, 1991, at E1 (citing 1990 Yankelovich Clancy Shulman poll). A second 1990 poll found that since 1985 the number of all women who would rather be homemakers than employed outside the home had risen from $45 \%$ to $51 \%$. "This marks a stunning reversal from the previous decade when the number of women preferring work outside of the home grew from $35 \%$ in 1975 to $51 \%$ in 1985, and the number wanting to stay at home dropped from 60\% to 45\%." Tense Times, supra note 174 (citing Virginia Slims Poll). See also George H. Gallup, Jr. \& Frank Newport, Virtually All Adults Want Children, but Many Reasons Are Intangible, GALLUP POLL MONTHLY, June 1990, at 22 (finding that if money were not issue, half of all working mothers would stay home).

176. In a 1990 poll, $66 \%$ of mothers said that the conflicting demands of family and work "put them 
The New Right's ideology of division channels that dissatisfaction toward welfare mothers: why should a woman who wants to be a homemaker have to work outside of the home and support through her tax dollars the AFDC recipient who has the "Iuxury" of staying at home to raise her children?" This sentiment has prompted behavioral modification proposals like Learnfare and Family Cap, which seek to punish and devalue the "nonproductive" mother for the ostensible reason that she at least should exercise some control over her children and stop getting pregnant.

This attempt to use economic motivation to create changed behavior in AFDC mothers and children leads to "solutions" that are contrary to empirical evidence and thus cannot solve the problems for which they are ostensibly designed. "Welfare reform" programs such as Learnfare and Family Cap do not solve burgeoning social problems; they reflect only political expedience and culturally biased mythology.

under a lot of stress." Tense Times, supra note 174.

177. See 133 CONG. REC. H11,515-16 (daily ed. Dec. 16, 1987) (remarks of Rep. Roukema) (opposing Family Support Act). In 1972, 49\% of adults surveyed believed that mothers receiving welfare should be required to take any job offered them. Gallup Poll, May 1972, available in DLALOG, File No. 468. In 1991, $79 \%$ favored requiring all mothers on welfare to do work for their welfare checks. Gallup Poll, November, 1991, available in DIALOG, File No. 468. By 1992, 80\% favored such a requirement. Gallup Poll, April 1992, available in DIALOG, File No. 468. The stereotype of the perennially unemployed mother again uses only a subset of the AFDC population as a symbol of the unworthy poor. Thirty-nine percent of single AFDC mothers in a recent study either combined work with welfare, or alternated between them during a two-year period. The race of the mother was not a predictor of whether the mother would go into the labor market. INSTITUTE FOR WOMEN'S POLICY RESEARCH, COMBINING WORK AND WELFARE: AN ALTERNATIVE ANTIPOVERTY STRATEGY 9-19 (1992).

It is not surprising that at the same time that policymakers are trying to use the minuscule AFDC budget to address major systemic problems of poverty, states are not spending even the money already appropriated under the Family Support Act to implement job programs designed to move AFDC mothers into the labor force. JAN L. HAGEN \& IRENE LURIE, THE NELSON A. ROCKEFELLER INSTITUTE OF GOVERNMENT, STATE UNIVERSTY OF NEW YORK, IMPLEMENTING JOBS: INITIAL STATE CHOICES, SUMMARY REPORT 6 (1992). 